\title{
Beyond Abyssal Thinking: The Deep Decolonization of the Studies on War and Violence in Contemporary Mozambique $^{1}$
}

\section{Maria Paula Meneses}

Center for Social Studies, Coimbra University (Portugal)

Based upon a critical reading of the civil war that left a profound mark in Mozambique (1976-1992), this article intends to contribute to present-day debates over the importance of peace studies in state building, addressing the cultural resistances that frequently go undetected. At the same time, this article -rooted in the political and epistemological proposal of Boaventura de Sousa Santos' abyssal thinking (2018) — aims to theorize the political events that permeate this conflict, transcending the (pre)dominant interpretations of the global North. In this sense, this study -from a concise analysis of the geopolitical complexity of the civil war- addresses inherent resistance, prioritizes local voices and explanations, and thus expands the analysis of the root causes of the conflict. Additionally, and stemming out of the epistemologies of the South, it aims to expose situations of cognitive injustice in "international" readings of this war, while - from a contextual reading of wars within the Mozambican civil war- it presents clues for a methodological approach that paves the way for a deep decolonization of security and peace studies.

Keywords: epistemologies of the South, cognitive injustice, Global South, decolonize peace studies, heterogeneous state.

1 This articles draws upon research conducted in Mozambique since mid-1990s. I am very grateful to all the people - interviewees, archivists, and many others - that have taken time to support the study and to discuss the results. A special word of gratitude to Boaventura de Sousa Santos, whose encouragements contributed to shape up this article, and to Ana Isabel Rodríguez, for the challenging invitation to critically assess narratives of peace, conflict and security from the perspectives of the Epistemologies of the South. Finally, I want to express my gratitude to the two anonymous reviewers whose comments contributed to (hopefully) clarify the arguments of this article, enriching it. 

he violent reality of armed conflict marks the Mozambican territory since the 1960s (Coelho, 2009). Specifically, in what concerns civil war - extending until $1992^{2}$ - , the great majority of academic analysis of this conflict base their focus on a national scale (Minter, 1994; Morier-Genoud, Cahen and Rosário, 2018), which is often an abbreviation of the modern nation-state. A nested system de absences and silencing of actors and their knowledges - from the national to the international institutions - has produced recurrent episodes of armed violence in central and northern Mozambique, many of them exposing unresolved conflicts of the past. A deeper understanding of the roots of these conflicts require, on one hand, a review of the modern project of nation-state, a colonial legacy (Ling, 2014) whose analytical categories are keen in studying conflicts and statebuilding. On the other hand, it requires wider scrutiny over the nature of actors involved in statebuilding, starting with a criticism of the monoculture of political knowledge, an essential element for the modern scientific reading of contemporary African political conflicts (Meneses, 2019). The predominant dichotomies used in peace studies —order/disorder; modernity/ tradition; identity/alterity; inside/outside-, have resulted into studying world politics through the prism of an either/or logic and through the condition of separation (Sharma, 2021: 26). Consequently, in many of the institutionalist perspectives put forward by individual African states, African regional groups, the African Union and other international organizations in handling security issues, peace studies and statebuilding, the analytical focus has been on cooperation and competition among them (Coleman, 2011). The emphasis is usually placed upon the interactions that reproduce the performance of the international institutions anchored in the North. As stated by Ayrton Aubry (2021: 1), little agency is given to Africa actors and institutions in imagining and implementing alternative approaches to peace and security, beyond the still impinging colonial institutions and their knowledge.

The shaping of Mozambique by modern colonial institutions was not limited to the imposition of a set of limitative norms; on the contrary, colonialism represents a collection of axioms, concepts, and discourses through which metropolitan institutions sought (and still aim at) - to represent complex African political realities as an object of knowledge, built from the perspective of the Global North (Meneses, 2018). This representation is at the origin of the radical abyssal fracture dividing metropolitan and colonial contexts: the former, symbolically represented as the Imperial North, is inhabited by lawful citizens; while the latter, the colonial context, is mostly described as being inhabited by underdeveloped ethnic groups, without a legacy to pass on. This radical division between metropolitan and colonial realities - and social relations present

2 For many authors, the introduction of multi-party elections and the 1992 Rome peace agreement are initiatives that sought to end the country's ongoing civil war (Manning, 2002). However, this political approach has failed to translate into a successful turn towards reconciliation and peace. 
therein-compose what Boaventura de Sousa Santos defines as abyssal thinking, a form of interpretation so insidious that survived until the present times (2018: 30 ), allowing for the continued exclusion of institutions and knowledges ${ }^{3}$ from colonized territories from all political analysis produced in the Global North.

This article, stemming from the abovementioned political and epistemological proposal expressed by the abyssal thinking, intends to theorize over ways of thinking about political realities silenced by modern Northcentric interpretations, with a focus on contexts affected by armed conflict. Specifically, this article focuses on the analysis of the Napharama, ${ }^{4}$ a counter-violence movement (19881991) that decisively intervened in the course of the civil war. In methodological terms, this study is based on interviews with individuals involved in the civil war, as well as on the analysis of newspapers of that period, as well as on secondary sources that were published. ${ }^{6}$ Together, the critical study of these sources adds cultural density to the readings of this war, by unveiling agents central to the analysis of civil wars beyond the Cold War paradigm in Southern Africa (Onslow, 2009). Often categorized as a low-intensity, intra-state conflict, the Mozambican civil war is notorious for the scale of human suffering and lives lost over its duration, revealing various alternative paths to peace advanced bottom-up.

The article starts with a brief introduction to the abyssal exclusions that shape contemporary Mozambican political order. A short presentation of the reasons for the civil war follows, to discuss, further on, the meaning of the political and cultural resistance in the actions of the Napharama. The article ends with an interpretation about the importance of incorporating other knowledge systems into the political analysis of Mozambique. By fostering an ecology of knowledges in the exploration of the political landscape of social and political struggles in Southern Africa, this article intends to be a contribution to the decolonization of knowledge, thus overtaking situations of cognitive injustice still permeating studies for peace and security in African contexts (Meneses, 2009; Sabaratnam, 2017).

The growing presence of the epistemic South has been exposing how the dominant geopolitical interpretation, produced in the Global North, is the projection of localized political interpretations. This knowledge still sets the

3 The use of knowledges in the plural is used to refer to distinct, different knowledges, stemming from different contexts, times, people, etc.

4 In Emakhwa, the main idiom of the Centre-North region of Mozambique, where this episode of "counter-violence" occurred, napharama means "unbeatable force" (Cuhaela, 1994). Parama also refers to the drug used for vaccination. Thus Napharama became a term that designates people that have been vaccinated (Jentzsch, 2018: 75). Alternative forms of writing include Naprama, Barama or Parama (Wilson, 1992: 561).

5 The interviews used in this article were carried out with former militia and military who took part in the war; they were carried out between 2002 and 2004, almost a decade after the peace agreement, mainly in central-northern Mozambique.

6 Official reports, both from Mozambique and abroad. 
16 tone for many contemporary analysis, by establishing as "legitimate", as leading and as forward-looking the knowledge produced in the Global North, which insistently aims to impose itself, seductively, as universal knowledge. As MichelRolph Trouillot highlights, this "universal" is prescriptive, "inasmuch as they always suggest, even if implicitly, a correct state of affairs — what is good, what is just, what is desirable-, not only what it is, but what should be" (2002: 221). In what concerns time, the political options followed in the last decades have been underappreciating other dimensions of the political conflicts present in Mozambique, generally interpreting them as "traditional" cultural expressions, with a residual value, or of anthropological interest. For the Northcentric views, the best solution for instabilities, crisis, famine and natural disasters affecting the Global South rest upon the building of the monocultural nation-state, resorting to modern institutions and the grammar of modern normativities (Inayatullah and Blaney, 2004; Benton, 2009).

By maintaining the idea of a national political project based on a modern democratic proposal —one stemming from the Global North (Vines, 1996; Cabrita, 2000)—, Mozambican policy makers have been contributing to the erasure of an historical past with intricate diplomatic plots and pre-colonial policies, thus silencing latent experiences and lineages of conflicts. This approach, with deep roots in modern colonial projects, does not take into account(s) the presence of traditional authorities, traditional justice and governance mechanisms, critical aspects of statebuilding in a country connected also through spirit mediums and healers (Meneses, 2012). ${ }^{7}$ As pointed out by Sanjay Seth (2011: 170), to write about war and international geopolitics cannot be done without engaging the disciplines which takes these topics as their specific subject matter, and without indicating why and how it is necessary to go beyond the still predominant analytical approaches.

Opposing the disciplinary grammar of peace studies about Africa that mirrors an epistemological crisis produced by the Northcentric abyssal thinking, this article strives for a dialogue with other political references that can help to understand the world beyond the references of the Global North, highlighting the ideas of ontological positioning and epistemic and political diversity of the contemporary world. ${ }^{8}$ This reasoning can therefore be inscribed in the wider context of the epistemologies of the South, which are "a time of epistemological imagination aimed at refounding the political imagination [...] to strengthen the

7 This is not a unique case. See, for example, the case of neighboring Zimbabwe, where various scholars have studied the impact of spirit mediums on the guerrillas during the liberation struggle (Lan, 1985; Ranger, 1985).

8 An important literary pool exists, produced in African contexts, that precedes the current wave of studies about the African political experiences in the context of debates about the Global South. See, amongst others, Rodney, 1972; Ake, 1979; Thiong'o, 1986; Mudimbe, 1988; Hountondji, 1997. 
social struggles against domination" (Santos, 2018: 126-127). While "occupying" the conventional concept of epistemology, the epistemologies of the South aim to promote the production and validation of knowledges anchored in the experiences of resistance and struggles of social groups that have experienced injustice, oppression and even destruction caused by capitalism, colonialism and by the patriarchate (Santos, 2018). Different knowledges have distinct identities, leading to articulations - among them- which are a result of the needs and objectives of social struggles. The concept of "South" is not used as a reference to geographical locations, different development stages or even localized cultural differences. In this context, the South refers to a shift in the epistemological relations of power, to deal with conflicts via the participation of the people and not acting on people, to assert positions and proposals of local actors in conflictaffected regions. To approach peace studies beyond the predominant disciplinary angle involves recognizing the cognitive diversity of the world. By promoting the dialogues across knowledges on peace and statebuilding -example of ecologies of knowledges-, expose, on one hand, the disciplinary complicity of peace studies in reproducing binaries and certain colonial hierarchies. On the other hand, by claiming recognition, legitimacy and visibility of the multiple experiences present, it becomes possible to develop procedures capable of promoting inter-knowledge and inter-political translation, strengthening the struggles and claiming fuller citizenship.

On the surface Mozambique presents all the characteristics of a modern state. However, a detailed analysis of the Mozambican civil war highlights the important role of other agents, beyond the state and the key military actors, in seeking alternative paths to solve conflicts. These agents, institutions and norms, important as they are in various African contexts, are largely treated by mainstream peace studies and statebuilding as secondary issues and/or ontologically derivative effects of some "previous" discrete "ontologically priors" (Sharma, 2021). Thus, this article calls for a study of contemporary Mozambique as a constellation of political, ontological and epistemological aspirations, expressed through numerous conflicts and struggles. It expresses an epistemological South, integrating multiple epistemologies produced when and where the struggles take place, confronting several cultural, historical, political, social and even circumstantial contexts, whose experiences are also a part of world history. Temporally, the return of those considered the wretched of the earth (Fanon, 1961) is one of its key characteristics. The passivity and inability to change, previously identified by the colonial project as characterizing the "colonial subjects", is being actively challenged by those who saw their experiences silenced, their knowledges erased, and their institutions shamed and negated (Meneses, 2012). 
18 DRAWING A LONG-LASTING GEOPOLITICAL ABYSSAL LINE

Any analysis on modern nation-states has to apprehend the impact of the settler's colonialism in contemporary African contexts (Nkrumah, 1970: 62-63). ${ }^{9}$ Law played a fundamental role in colonial settlement, and was central for the maintenance of the violent racial and spatial differentiation between colonizer and colonized, through the insertion of a dividing line which Franz Fanon (1961: 31) defined as represented by the barracks and the police stations. A detailed analysis of the modern law and state shows that it has not developed from European diplomacy but from violent fifteenth-century territorial invasions by the Spanish against the indigenous populations of the Americas (Anghie, 2005: 15), inaugurating modern settler's colonialism.

One of the key characteristics of settler's colonialism is the attempt to destroy what exists on the other side of the abyssal line: people, knowledge, political structures, etc. The desire for land appropriation as a resource is the foundation of various episodes of genocide, forced displacement, and coercive forms of cultural, social, and political assimilation. Across the Global South, research on settler-colonial societies has focused on how, through the colonial relationship, indigenous policies and institutions are made to seem inferior to the newly Eurocentric ones, thus having less legitimate political claims. This proposition originated the idea of "juridical dualism", that is, the idea that in colonial and independent African states two major legal systems co-existed and struggled: the modern and the customary/indigenous, running parallel to one another with only limited, prescribed interaction (Griffiths, 1998: 133). However, societies that fell under the rule of colonialism were not mono-legal prior to the modern colonial encounter/intervention. Colonial intervention turned into one more source of legal order that became prominent because legal monism - the idea of a single unified non-western system- provided colonial rulers with a familiar legal platform.

Modern colonialism acted simultaneously as a practical civilizing mission and as an ideology based on an epistemology created by modern rationality (Merry, 2003). At the core of this project was the attempt to impose and to legitimize the domination and exploitation of the local populations, transformed into colonial subjects. Colonialism divided the population between citizens and subjects; between those ruled by modern law and those to whom "traditional" -indigenous/customary - rules applied for the resolution of problems of local African societies. This rationality entitled enlightened rational beings with the right to liberate the colonized from his/her "ignorance"; in parallel, on the other

9 In the case of Mozambique, settlement colonialism was activated through the exhortation of institutions and rules serving settler's populations that migrated to the region since the late 19th century (Meneses, 2018). Despite the independence, this form of colonialism cannot be seen as a thing of the past, as the socio-legal structure of oppression and political administration remains present in the form of the modern nation-state, as discussed in this article. 
side of the abyssal line, it produced colonial subjects, waiting to be rescued from their historical yoke. This mode of ruling, as described by Mahmood Mamdani (1996: 18), gave rise, in various colonial contexts, to a bifurcated state. "It was about incorporating natives into a state-enforced customary order", where the tribal authority concentrated the administrative, judicial and executive power. In this process, local norms were reduced to — and crystallized into- "customary law" of ethnic groups.

The combination of the political judgement with a moral stance resulted in the construction of monolithic traditional norms, in opposition to the modernity of the nation-state. The now ethnicized norms were shaped to accentuate the extent to which the world of the indigenous did not correspond in any way with the civilized one. Therefore, for being on the other side of the abyssal line, it could not "serve as the basis for a common experience of citizenship" (Mbembe, 2017: 86). The application of this political project revealed that the implementation of a modern state administration relied on the modification of other norms as a primary mode of governance. The colonial state did so, first and foremost, through the state's recognition of such diverse authorities as to the "tribal" chiefs, and the incorporation of those authorities within the authority structure of the state, now transformed into local, traditional authorities, vis a vis the official modern administration.

In the case of Mozambique (Meneses, 2012; 2018), the structure introduced with Portuguese settler-colonialism sought to eliminate the indigenous as an equal human being, as the key goal of the colonial administration was to identify the existing structures of conflict resolution, to be transformed into subaltern ethnic structures, with knowledge of limited, local value. One of the fundamental dimensions of colonialism least addressed is its inability to listen and to get to know the colonized other as a political actor, with experiences and with knowledges. In line with Achille Mbembe (2017: 78), the colonial alterity has to be understood as a condition "in which the self becomes unrecognizable to itself"; furthermore, this author adds to the colonial characterization the idea of expropriation, a process that includes "a singular experience of subjection characterized by the falsification of oneself by the other. What flows from this is a state of maximal exteriority and ontological impoverishment".

As emphasized by Mamdani (1996: 39), colonialism embodied a well-defined political and cultural model, methodically crafted in order to be imposed on Africa, so that colonizers could govern in an effective and sustainable way. In short, the modern nation-state, crafted outside the continent, has insistently aimed to impose itself as the most sophisticated model of governance, without questioning its own limitations. This model, with long-lasting consequences, was right from the inset highly hierarchical, patriarchal, and authoritarian. With independence, colonial institutions remained in place, both politically and institutionally. Through this monocultural political system, social actors have sought to (re)produce discriminations, by insisting on coding otherness as ethnic, racial or national differences, according to the contexts, agents and populations involved. Studies of law and colonialism reveal the contradictory objectives of colonial rule, its intended and unintended consequences, and 
the force and fallibility of colonial power. More importantly, however, these dynamics show the changes and continuities between the colonial time and the "developed present", in the structure of the modern nation-states and around the notion of sovereignty that African countries have inherited in association with this project. This short analysis deflates the idea that colonialism ended with the independences because socio-legal structures of oppression and political administration remained in place. A critical evaluation of the modern state has to expound on how it cannot exist without capitalism's capacity to extend itself, by inhabiting and territorializing itself in the form of national difference, colonial difference, civilizational difference. This difference represents the abyssal thinking, the insistence of the "modern side of the abyssal line" - controlled by modern rationality - in defining which sites are "global" and which experiences are continuously recomposed as peripheral, inhabited by subhumans that do not need to be understood precisely because they are outside the modern political community. Arturo Escobar' analysis clearly reveals how the colonial metropolitan modernity projects have appropriate the right to be "the" world, subjecting all other worlds to their own terms or, worse, to nonexistence (2015: 3). However, despite this colonial preponderance, other systems of knowing and being have continued to exist in parallel as the living knowledge traditions and practices of the colonized peoples. Their experiences continuously produce knowledges that offer the possibility of re-claiming thought and action, cognitive justice. For example, the role of spirit medium is addressed by existing literature on post-conflict Mozambique especially as key actors performing cleansing and reconciliation rituals (Honwana, 2002; Igreja, 2012). However, the key role of spirit mediums and healers in contemporary Mozambican conflicts and post-conflict contexts are central in the leading research about the civil war and statebuilding. To comprehend, from the perspective of peace studies, the possibilities of overcoming the conflicts in Mozambique requires the recognition, both from national and international actors, of the complexity of the existing hybrid political orders. This article introduces the debate about the interactions between healers and the state, calling for a deeper study of the interaction between the world of the living and the ancestors. Furthermore, it underlines the significance of addressing the role of healers and spirit medium as part of the heterogeneous socio-political structure of the country (Santos, 2006: 42).

\section{THE “NEW” POLITICAL NATIONALISM AND THE RETURN OF ARMED VIOLENCE}

The tension between the national project proposal — with a modern territorial basis, well mapped, well legislated and well historicized by the colonial handand subsequent (re)constructions of the various identities present in the geocultural territory identified as contemporary Mozambique, has resulted in cohabitations that have been all but peaceful —although seen this way by the powers in place - and were little prone to dialogue. This state of things is manifest in the consecutive reconfigurations of the identities in tension -ideological, 
ethnic, racial, religious-, which generated other presuppositions and other defining concepts of other geo-cultural places, also named Mozambique, keepers of other cultural, linguistic and religious repositories.

In the 1960s, the creation of FRELIMO ${ }^{10}$ - a nationalist movement - was a fundamental moment in the struggle against Portuguese colonialism in Mozambique, a process that gave birth to social and political changes accelerating with the independence, in June 1975. FRELIMO's vision regarding the real independence of the country was rooted in a nationalist project presupposing a rupture with the colonial, capitalist and traditional past. The most visible expression of this project was the great narrative of the armed struggle, centred in denouncing colonialism and its vices (discrimination, exploration, subalternization, etc.) and in the elaboration of an alternative national vision; rooted, also, in the knowledges and experiences of the groups which integrated the Mozambican social fabric (Meneses, 2012). This project favoured a proposal that outpaced the ethnic fractures that characterized the country; however, in this project, indigenous/traditional spiritualties -identified by FRELIMO as a sign of pre-colonial ethno-political references- found no place (Machel, 1974: 35). It was from this narrative - promising a future and not revising the past, nationalist and organically local but with a strong legacy of the Northcentric colonial project - that an objective, and a directive sense of being a Mozambican, arose. The modern call for equality dramatically erased the differences composing the social fabric of the country, accentuating previous contradictions.

Indeed, the cultural diversity of the country was not taken into consideration when drafting the first constitution, signalling a continuity with the colonial political processes (Meneses, 2015). By seeking to break up with the power and influence which traditional politicians and religious/spiritual instances held, FRELIMO — which would soon turn into a political party- promoted a series of actions against practises and ceremonies likely to legitimize the so-called traditional power. Rain ceremonies and fertility rituals, to name just two, were forbidden. This process resulted in deep uneasiness, and even resentments from those authorities (Meneses, 2012; Jentzsch, 2018). In Ventos do Apocalipse [Winds of the Apocalypse], the origins of the civil war in Mozambique are justified by Paulina Chiziane:

Because the people lost connection with their history. [...] The confrontation between traditional and imported culture was the cause for an unsettlement of the people, which generated an identity crisis. We are so overloaded with ideas estranged from our culture that very few, or even nothing, remains from our genesis. We are a band of wretched people with no past and no future. If we ignore who we are and where we come from, we will obviously not know which path to follow (1999: 258).

10 Frente de Libertação de Moçambique / Mozambique Liberation Front, the main nationalist movement involved with the independence and self-determination of the country. In 1977 it was transformed into a political party, Frelimo party, active in the political-administrative management of Mozambique. 
The refusal to accept the African-based forms of religion and spirituality in place, as well as the attempts to abolish other local political authorities which could dispute Frelimo party's authority, resulted in growing opposition to government policies, and to Frelimo being constantly made responsible for the moral crisis sweeping the country (Geffray, 1990: 203). In the first decade of independence, Frelimo's political options rested upon a socialist orientation of the economy, as a means to overcome the underdevelopment situation, a legacy of the colonial past. This option, decided in a Cold War context -associated with growing isolation regarding the minority neighbouring regimes, main economic partners of Mozambique-, helps to explain the growing crisis in the country (Finnegan, 1992: 31). If in 1976 the Rhodesian armed forces -with the implicit support of apartheid South Africa- came to launch a series of attacks on civilians in the Mozambican territory (Smith, 1997: 195-196). This strategy of opposing Mozambique political project would soon change, with those countries supporting the constitution of a rebel movement that became known as Resistência Nacional Moçambicana - RENAMO ${ }^{11}$ (Minter, 1994). The war opposing Frelimo's government to RENAMO left deep scars over the country, and a tragic balance: between 600.000 and one million people lost their lives, and more than 200.000 children became orphans. The conflict was also at the origin of migratory movements, with 1,7 million refugees in neighbouring countries, while more than 4 million Mozambicans have sought refuge in urban spaces and other government-controlled areas. ${ }^{12}$ Although a Peace Agreement was negotiated and signed in 1992 between Frelimo's government and RENAMO, peace is still to come.

One of the characteristics of this armed conflict is the use of "neo-traditional" ways to fight, an example of which is the Napharama's magical, spiritual war (Roesch, 1992: 472; Pereira, 1999: 61-63). During the interviews conducted regarding the origins of the war, most people pointed fingers at the military from both sides, accusing them of spreading the war chaos. Over and over again people attributed to taboo breaches on the soldier's part the origins of the spirit's rage that was the cause of their suffering. In a context where the state and the "formal" military forces involved were detached from the people, and the hopes for peace from above were nil, cults of counter-violence took place in various moments and places, as reported in various interviews. Through these cults the populations sought to neutralize the advantage of military forces with the help of spiritual forces, relying on the idea that those spiritual forces could determine the outcome of the war and lead to the improvement of their lives (Wilson, 1992: 531-533; Jentzsch, 2018: 77).

The core of RENAMO's ideological motivation was linked with a religious idiom resting over the cult of the ancestors, with numerous commanding officers

11 In English, Mozambican National Resistance.

12 On this topic see, amongst others, Gersony, 1988; Minter, 1994; Chingono, 1996. 
of this movement reaffirming that the fight pursued by the resistance movement corresponded to a "war of spirits", one in which Frelimo was presented as a party of traitors of the national cause, relying on foreign - communist- projects; RENAMO, on the other hand, presented itself as being backed by ancestral spirits in the struggle for the return of Mozambique to Mozambicans (Roesch, 1992). While recognizing traditional authorities, and the symbolic and ideological value of healers and other individuals associated with spiritual cults, RENAMO went on benefitting from their support. In RENAMO's training fields, major decisions relating to armed actions of strategical nature were taken only after the opinion of healers had been heard, healers that "asked for the support of the ancestors so that RENAMO's actions would be successful"; ${ }^{13}$ it was also up to the healers and prophets to guarantee protection of bases from the attacks of governmental troops. ${ }^{14}$ Many RENAMO guerrilla members were sure to have been vaccinated with traditional remedies supposed to render them invulnerable to enemy bullets (Cuahela, 1994: 66).

From the perspective of the governmental army, although Frelimo's ideology rested over the refusal of recognizing traditional religions (Meneses, 2012), several situations were known when officials and soldiers consulted healers, but individually and in secrecy (Roesch, 1992).

This reality challenges several analysis of the Mozambican civil war, whose authors defend that "although ethnic and linguistic groups do provide linkages that ease mobilization and organization", these identities did not figure "crucially in the conflict" (Weinstein and Francisco, 2005: 186). In short, the heterogeneous nature of the Mozambican state seldom has been taken into consideration when studying the nature of war and peace processes, as the Napharama case exposes.

\section{RE-CREATING RESISTANCES, RE-CLAIMING KNOWLEDGES}

In the 1980s, the increase of armed actions exacerbated, devastatingly, the ill political, economic and social environment of the country (Chichava, 2007). In the words of Ba Ka Khosa (2008: 32), the war had become something organic Seeking to intervene in the conflict in their own favour, communities turned to their ancestors searching for support and protection. With those cults, expression of other cosmovisions, people not only gave a different interpretation to that war but also constructed struggle possibilities in the face of a lack of a solution for the extreme violence problem overtaking Mozambique. This interaction, at a community level, expressed the strength of local actions in contexts where state structures proved unable (Igreja, 2012). Those counter-violence cults, and other struggles within the civil war, proved fundamental for the recreation of

13 Interview with Timóteo F., former RENAMO combatant in Angoche, August 2004.

14 Interviews with Simeão F. and Mário J., former members of government army in Magude, April 2000. 
resistances from communal experiences and knowledges. These knowledges are foundational to rethink systemic change from a dynamic standpoint (one state with multiple cultural and epistemological references), from the recovery and transformation of the political meanings of religion and spirituality. One such case is the Napharama, an armed people's movement born in Nampula province in 1988-1989, which then spread to the neighbour provinces of Zambézia and Niassa. ${ }^{15}$ Manuel António led this movement - a young Makhuwa described by those who knew him as an humble person, under thirty years old and with few studies. ${ }^{16}$

The counter-violence cult of the Napharama, as evaluated by Ken Wilson, explored RENAMO's Achilles heel by outgrowing the terror strategy used by the movement to assure control over the populations (1992: 561). Armed exclusively with spears and machetes, those popular militias confronted RENAMO's combatants, who made use of sophisticated military equipment. Government members, religious and intellectual leaders, and also Manuel António himself, explained the emergence of the popular movement as a self-contained resistance force, one reaffirming an alternative to the war and terror conducted by RENAMO, where cultural and spiritual resources were the only way to give birth to an alternative to this war. ${ }^{17}$ However, one should underline the loose alliance that, already by then, linked this movement to governmental troops. In fact, the Napharama group counted, on numerous occasions, on administrative and military support from the government. That recognition made several RENAMO soldiers report that "the government resources to spirits to combat against us", ${ }^{18}$ thus revealing the strength of spirituality in the history of struggles and resistances in this region.

Easily identified by a lace made with a piece of red fabric tied to their weapons, Napharama men were vaccinated with a special remedy before integrating the force, a vaccine which was rubbed over three cuts in each men's chest; after that, they were plunged into water and had their bodies rubbed with oil. This ritual was conducted by Manuel António himself, who was also a healer. He maintained having died from measles as a child, resuscitating six days after that.

15 "The Warrior 'Priest' Brings Peace to Zambézia", The Weekly Mail (Johannesburg), 1218 April 1991.

16 Manuel António came from the Makhuwa-Lomwè linguistic group; a group which, at the time, had only minor relations with Frelimo. However, given the profile of people supporting the Napharama, it is not possible to affirm that it was a tribal-based movement, a movement set in social institutions and organizations with an ethnic root.

17 Alfredo Gamito - then the Governor of Nampula province- stated: "People, weary of war, embrace superstitious beliefs as a path to finding a solution for war itself" (in Mozambiquefile, 2 May 1991; see also “Crónica de Viagem: Os 'Baramas'”, Jornal Domingo, 14 July 1991).

18 Group interview with former RENAMO fighters in Nampula, August 2004. Weapons and soldiers captured by the Napharama were usually rendered to governmental forces ("Local Militia Counter Offensive", Mozambique Information Office, 202, 30 May 1991). 
While dead - he stated-, Jesus had told him that his mission on earth would be to liberate his people from the sufferings of war (Legrand, 1993: 99). After living for six months at the bottom of a mountain, he had learned from the spirits how to protect "his people". Explicitly, the spirits had taught him the secret of a vaccine that rendered people immune to enemy bullets. ${ }^{19}$ The Mozambican daily newspaper Notícias - a Frelimo's government newspaper- described the Napharama's movement as a new form of an organization against violence, stemming from an old idea of protection against bullets through the power of traditional vaccines. ${ }^{20}$

Several bans weighed on Manuel António's militias: to rape women, to argue and to steal from the populations, to shake hands with married men or women, to have sexual intercourse with women prior to any military action, to eat before any military action, etc. ${ }^{21}$ On the military field, the use of firearms was forbidden; furthermore, they could never retreat from enemy attacks, or show fear. As in other situations of spiritual empowerment, those men believed that the breach of any of those taboos would result in death in combat, for having lost their strength and the protection given by ancestral, hidden forces. After every action, the Napharama went through cleansing rituals, to appease the ancestors and assure their continuous protection (Chichava, 2007). ${ }^{22}$ Populations under the protection of those rituals were also subject to several rules and interdictions (Pereira, 1999).

The Napharama militias were not a permanent force, nor they assumed themselves as an alternative political force. During the day, they worked at home or in the fields, taking arms against RENAMO only when necessary. On those occasions, they established groupings of hundreds of men armed with spears and machetes that, at a fast pace, blowing horns and shaking cans, charged over the enemy. Manuel António himself is quoted as having stated to Radio Mozambique that he "served the interests of the people and had no political ambitions". ${ }^{23}$

The restriction on the use of firearms was justified by the defensive nature of the movement. As Joaquim Vista — by then one of the Napharama commanding elements- explained, "our mission is of a defensive nature only; we are defending the people, because they are tired of war". ${ }^{24}$

19 "António's Triumph of the Spirits", Africa South (Harare), May 1991, pp. 14-15; "Local Militia Counter Offensive", Mozambique Information Office, 202, 30 May 1991.

20 "Anti-balas ou Naparamas", published in Notícias, 15 May 1991.

21 See "Os 'Naparamas': Novos desenvolvimentos observados em Nampula”, Notícias, 1 June 1991.

22 "O fenómeno do 'Naparama' num encontro no Gilé", Notícias, 2 May 1991; "Nampula: Uma longa viagem", Tempo magazine, 24 November 1991, p. 15.

23 See Indian Ocean Newsletter, 16 February 1991.

24 "Barama: Uma força libertadora", newspaper Domingo of May 5, 1991; "O fenómeno do 'Naparama' num encontro no Gilé”, Notícias, 2 May 1991. 
At its peak, the Napharama's movement included about 20-30.000 men. And despite of the superiority of their weaponry, RENAMO's forces were terrified whenever those militia groups approached. The Napharama achieved remarkable progresses in the military terrain, which allowed the return of thousands of displaced people to their areas of residence. ${ }^{25}$ From mid-1991 onwards, tensions rose amongst the Napharama, mainly over questions about the use of power, connections with the governmental armed forces, ${ }^{26}$ with the Government itself and with the Catholic Church. ${ }^{27}$ At the same time, and given the massive expansion of this counter-violence movement, RENAMO pinpointed it as the central target for their military actions in the centre-north regions of Mozambique. While Manuel António tried to widen the basis of his movement through an active syncretism, that wager resulted in a growing personal alienation from the Catholic Church, in an area where the Church was identified as supporting people' actions. Those facts, together with the profound debate over the relations that the state-party Frelimo should maintain with the Napharama, help to explain the crisis that broke out, a crisis that resulted in the death of Manuel António in December 1991, in the Zambézia province. The causes for his death remain a mystery, being attributed by the interviewees to an error in his ritual preparation for a planned trip, and not to the weakness his movement was experiencing. By then, the strength of the movement was such that the death of Manuel António made news in numerous newspapers, nationally and abroad. ${ }^{28}$

For the cultural language familiar to the populations, the Napharama were a proposal to reacquire control over their own destinies, of putting an immediate end to the war. RENAMO, despite its political rhetoric, had not been able to present and implement a market development program for the peasants (Wilson, 1992: 567); on the contrary, the war waged by RENAMO was leading the peasants back to poverty. This explains why, in places where peasants had sought refuge, the decision to engage with the Napharama had grown. ${ }^{29}$ This strategic option was a peace strategy that involved the return to a culturally-based normality. As

25 Those military actions took place at a time when the government's position regarding traditional authorities was one of profound inflection towards rapprochement (Meneses, 2012).

26 In 1991, the number of soldiers willing to pay to be vaccinated by Manuel António was growing, while the vaccine had been previously free of charge, a token of the person's commitment with the movement's struggle (Wilson, 1992).

27 Although several priests recognized the importance of the Napharama's struggle, to many that movement was a symbol of 'a spell turning against the sorcerer', by defying even RENAMO's violence cults. Following the subordination and even criminalization of local beliefs by the Catholic Church, the Bishop of Zambézia at that time described the Naparama as being involved in a "psychological war" based on superstitions. See "Manuel António - A sombra do Naparama", in the catholic newspaper Pátria, 13 December 2007.

28 "Moçambique: A morte de um imortal", Expresso (Lisbon), 14 December 1991.

29 Group interview with peasants of Nametil, Nampula, September 2004. 
a Napharama commanding officer - Bento Piquina - pointed out, "to fight with the strength of spirits makes us stronger than our enemies". ${ }^{30}$

The success of the Napharama can be explained by the fact that they shared - even with a large contingent of RENAMO - the same cultural references, where a belief in "hidden" forces as a banner of the struggle was a central element of local cosmology. Although the Napharama became the target of RENAMO's activities, the latter only beat them after (re)gaining superiority in the field of "hidden" powers. ${ }^{31}$ On the other side, Frelimo's government, by then already in a process of approximation to local authorities, did not insist in condemning the Napharama as obscurantists; on the contrary, actions of cooperation took place, as accounts were reported of government soldiers asking for protection charms so that they could be immune to bullets (Finnegan, 1992: 29). According to catholic religious circles, Frelimo quietly encouraged the re-emergence of public expressions of traditional spirituality, but as a means to drive the populations away from RENAMO; and thus formerly prohibited practises were reborn, with "commandants and governmental troops asking for the support of healers". ${ }^{32}$ The biggest difference lay, however, in the scale of acknowledgement. RENAMO's forces and the Napharama saw in regional spirituality and in traditional discourses an integral, epistemological, component of their struggle. In a violent conflict where all gestures and actions were linked with the wider world of ancestors, the popular militias of Manuel António achieved important victories, in territories where the governmental armed forces had proved incapable of penetrating. RENAMO's victory with the passing of Manuel Antonio meant that this movement was in control of more powerful forces than the ones helping the Napharama. Napharama healers even became associated with RENAMO, in "vaccination" and protection actions, assuring the invisibility of their forces, ${ }^{33}$ which seems to explain RENAMO's recapture of previous positions by the time of the Peace Agreement of 1992.

In short, the dimension of the Napharama movement illustrates how healers and spirit mediums are key actors in the Mozambican political system, a fact that has implications for understanding statebuilding in post-conflict contexts. Indeed, these actors guarantee the connections between the spiritual realm and everyday experiences of peace and justice, a fundamental characteristic of their approach to conflict resolution. Their strategic importance has been at the core of the processes of explicit and implicit negotiations of key national powers - government and RENAMO forces - with healers and spirit mediums, aiming at gaining concealed access to the forces and experiences of these political key actors.

30 "Spirits high as 'bullet proof' Mozambicans topple rebels", The Daily Telegraph (London), 4 July 1991.

31 Interviews with several former combatants of RENAMO in Angoche, in September 2003 and August 2004.

33 Interview with Joaquim B., former RENAMO combatant in Angoche, in September 2003. 


\section{EXPANDING THE ANALYSIS OF WAR TO OTHER EPISTEMOLOGICAL POSITIONINGS, PROMOTING AN ECOLOGY OF KNOWLEDGES}

A deeper reading of the violent armed conflict that Mozambique experienced after the independence shows how the strength of the spirits lingers as a central identity element amongst the multiple actors involved in that conflict. That strength, a cultural and epistemological reference in resistance struggles, was used and manipulated by different forces, mirroring a long history of combat for power and regional domination. Here, a fundamental role was played by healers and spirit mediums. To understand the importance of the Napharama in peace studies requires coming to terms with subjectivities relegated to the margins by modern Northcentric analysis. It illustrates the significance of addressing "knowledges born in struggles" (Santos and Meneses, 2019) of un- or misrepresented human groups to speak for and represent themselves in domains from where they have been historically excluded, such as present day security, peace studies and statebuilding.

In the opposite sense, an analysis of the multiple transitions Mozambique has known since the end of historical colonial times, the national project has been generating the fading of important cultural components. With the Peace Agreement of 1992, and with the opening of the country to liberal democracy and multi-party system, new narratives were born; different questioning moments emerged, as well as other "territories of violence", denied until then by imposed invisibilities. This new period demanded that the idea of being Mozambican was to be re-constructed, taking into account multiple identity roots in place. However, the ambivalence towards the recent past of the country remains an important political footprint, given the difficulty in separating the less known but violent sides of the recent historical process for the key political actors -Frelimo and Renamo.

As Meera Sabaratnam (2017) points out, the analysis of international interventions in post-war contexts exposes the presence of colonial parameters in the studies of global positions concerning power, authority, legitimacy, sovereignty, etc. The studies about peace processes in Mozambique, using Northcentric decoders, don't seem to be able to capture the density of cultural disputes and of the ontological claims. The Napharama movement, which finds similarities in other African contexts of armed violence (Weigert, 1996), calls attention to the deep historical and cultural roots of those conflicts, whose analysis and evaluation are vital for social appeasement and stability. To understand the political conflicts at the origin of the violent confrontation between Frelimo's governmental forces and the forces of RENAMO, it is necessary to go beyond the terms of the politicalideological dispute frequently reduced to the dominant dichotomies. To accept this perspective forces the analysts to acknowledge the modernization paradigm as a unidirectional breach with heirlooms from the past, without the ability or possibility of a dialogue and re-invention of those traditions.

To overstep this abyssal thinking — at the core of peace and security studies-, the ecology of knowledges proposed by Boaventura de Sousa Santos (2018) offers 
insightful suggestions regarding mutual intelligibility in intercultural and interpolitical translations. The ecology of knowledges revitalizes humanistic potentials of knowledge claims through disrupting the conventional hierarchical structures of knowledge production. By highlighting humanity's belonging to multiple worlds (Ling, 2014), the diversity and complex interactions of knowledge systems becomes a reality. Accepting that all knowledges are incomplete, even modern science, opens up possibilities for epistemic dialogue and contestation - a truly dynamic ecology. As this article suggests, studying conflictual processes involves addressing the epistemological plurality present as a core artefact. Understanding the roots of war encompasses deciphering all of the nuances involved in each conflict. In short, more often than desired, the dominant "disembodied universalism" present in peace studies limits the reading of any conflict, as the abyssal thinking insists in rendering as "non-existent, irrelevant, or unintelligible all that exists on the other side of the abyssal line", beyond the Global North analytical framework (Santos, 2018: 84).

To decolonize dominant peace studies, and to (re)construct a country where diversity is its strength, it is fundamental, on the one hand, to widen this field of studies to spirituality, recognizing the strength and importance of ancestral spirits and religion for the rebuilding of community, as an active force for the re-construction of the idea of being Mozambican. On the other hand, it is important to question the options emphasizing the "national" privilege in peace construction, rendering accountable all those possessing the political prerogative of not wanting to remember the waves of violence that scarred the recent past of the country (Meneses, 2019). The ultimate goal of post-abyssal research is to make researchers accountable in face of the people they are working with, rather than to their institutions. The alternative position advanced in this article - claiming for a deep decolonization and an ecology of knowledges - entails unequivocally the construction of meanings as a process of intercultural translation. This process implies dialoguing with pre-existing knowledges born out of experiences and struggles, a dialogue shaped by the lasting imprints of cultural encounters, the positioning of actors involved, and their engagement with the political struggle. This way researchers can build bridges over the multiple locales that nowadays compose our interconnected world, as well as over the lives of individuals and the political and historical contexts in which they dwell. In short, and in line with the challenges identified by Ananya Sharma (2021: 27), in order to overcome the abyssal thinking that still dominates most of the studies on war and peace, this article argues for the practice of relationality among different knowledges that form the socio-political fabric of Mozambique, thus supplementing the current decolonizing critical approach to research practices.

Maria Paula Meneses is a principal researcher at the Centre for Social Studies, University of Coimbra. A Mozambican scholar, she obtained her PhD in the USA, by Rutgers University. At the heart of her research interests are the relations between knowledge, power and 
societies, paying special attention to people who experienced the violence of the colonial encounter. She has conducted various projects on the postcolonial legal pluralism - with a focus on the relationship between the state and "traditional authorities" -, the relationship between official history, memory(ies) and other narratives of belonging in contemporary identity struggles. As an interdisciplinary scholar working across national and cultural borders, her perspective enables a robust and necessary challenge to stereotypes in relation both to knowledge production itself, and to the places and contexts in which that knowledge is produced.

Her work has been published in journals, books and reports in several countries. One of her recent publications, co-edited with Boaventura de Sousa Santos, is "Knowledges Born in the Struggle: Constructing the Epistemologies of the Global South" (Routledge, 2019), integrating contributions of scholars from Africa, Asia, Latin America and Europe, as well as Os Saberes Feiticeiros em Moçambique: Realidades materiais, experiências espirituais (Almedina, 2019).

\section{References}

Ake, Claude (1979). Social Science As Imperialism: The Theory of Political Development. Ibadan: Ibadan University Press.

Anghie, Antony (2005). Imperialism, Sovereignty and the Making of International Law. Cambridge: Cambridge University Press.

Aubry, Ayrton (2021). "African Solutions to African Problems: Appropriation in World Politics". CODESRIA Bulletin Online, 25, pp. 1-8, available at <https://codesria.org/IMG/ pdf/25-_aubry_african_solutions_to_african_ problems_.pdf $>$. Accessed 8 November 2021.

Benton, Laura (2009). Law and Colonial Culture: Legal Regimes in World History, 14001900. New York: Cambridge University Press.

Cabrita, João M. (2000). Mozambique: The Tortuous Road to Democracy. London: Palgrave Macmillan.

Chichava, Sérgio (2007). Le "vieux" Mozambique. Étude sur l'identité politique de la Zambézie. Bordeaux: PhD Thesis, University Montesquieu-Bordeaux IV.

Chingono, Mark (1996). The State, Violence and Development: The Political Economy of War in Mozambique. Aldershot: Avebury.

Chiziane, Paulina (1999). Ventos do Apocalipse. Lisboa: Editorial Caminho.
Coelho, João Paulo Borges (2009). "'Quantitative Literature' and the Interpretation of the Armed Conflict in Mozambique (19761992)". In: Rodrigues Udelsmann, Cristina and Costa, Ana Bénard da (eds.). Poverty and Peace in the Portuguese Speaking African Countries. Lisbon: Centro de Estudos Internacionais, pp. 88-106.

Coleman, Katharina P. (2011). "Innovations in 'African Solutions to African Problems': The Evolving Practice of Regional Peacekeeping in Sub-Saharan Africa". Journal of Modern African Studies, 49(4), pp. 517-545. <DOI: 10.1017/S0022278X11000462>.

Cuahela, Ambrósio (1994). História da Guerra na Zambézia. Um estudo da guerra em Namarrói, 1976-1996. Maputo: BA dissertation, Eduardo Mondlane University.

Escobar, Arturo (2015). "Post Development and Transitions: A Preliminary Conversation". Sustain Sci, 10, pp. 451-462.

Fanon, Franz (1961). Les Damnés de la Terre. Paris: Maspero.

Finnegan, William (1992). A Complicated War: The Harrowing of Mozambique. Berkeley: University of California Press. 
Geffray, Christian (1990). La cause des armes au Mozambique. Anthropologie d'une guerre civile. Paris: Karthala.

Gersony, Robert (1988). "Summary of Mozambican Refugee Accounts of Principally Conflict-Related Experience in Mozambique". Bureau for Refugee Programs, US Department of State.

Griffiths, Anne (1998). "Legal Pluralism in Botswana: Women's Access to Law". Journal of Legal Pluralism, 42, pp. 123-138. <DOI: 10.108 0/07329113.1998.10756519>.

Honwana, Alcinda M. (2002). Espíritos vivos, tradições modernas: Possessão de espíritos e reintegração social pós-guerra no sul de Moçambique. Maputo: Promedia.

Hountondji, Paulin J. (ed.) (1997). Endogenous Knowledge: Research Trails. Dakar: CODERIA.

Igreja, Victor (2012). "Multiple Temporalities in Indigenous Justice and Healing Practices in Mozambique". International Journal of Transitional Justice, 6(3), pp. 404-422. <DOI: 10.1093/ijtj/ijs017>.

Inayatullah, Naeem and Blaney, David L. (2004). International Relations and the Problem of Difference. New York: Routledge.

Jentzsch, Corinna (2018). "Spiritual Power and the Dynamics of War in the Provinces of Nampula and Zambézia". In: Morier-Genoud, E.; Cahen M., and Do Rosário, M. (eds.). The War Within: New Perspectives on the Civil War in Mozambique, 1976-1992. Suffolk: James Currey, pp. 75-99.

Khosa, Ungulani Ba Ka (2008). Os Sobreviventes da Noite. Maputo: Texto Editores.

Lan, David (1985). Guns and Rain: Guerrillas and Spirit Mediums in Zimbabwe. London: James Currey.

Legrand, Jean-Claude (1993). "Logique de la Guerre et Dynamique de la Violence en Zambézia". Politique Africaine, 50, pp. 88104.

Ling, L. H. M. (2014). The Dao of World Politics. Towards a Post-westphalian, Worldist International Relations. New York: Routledge.
Machel, Samora (1974). A Luta Continua: Antologia de discursos. Porto: Afrontamento.

Mamdani, Mahmood (1996). Citizen and Subject: Contemporary Africa and the Legacy of Late Colonialism. Princeton: Princeton University Press.

Manning, Carrie (2002). The Politics of Peace in Mozambique: Post-conflict Democratization, 1992-2000. Westport, CT: Praeger.

Mbembe, Achille (2017). Critique of Black Reason. Durham, NC: Duke University Press.

Meneses, Maria Paula (2009). "Justiça Cognitiva". In: Cattani, António; Laville, Jean-Louis; Gaiger, Luis Inácio, and Hespanha, Pedro (eds.). Dicionário Internacional da Outra Economia. Coimbra: Almedina, pp. 231-236.

-. (2012). "Powers, Rights and Citizenship: The 'Return' of the Traditional Authorities in Mozambique". In: Bennett, Tom; Brems, Eva; Corradi, Giselle; Nijzink, Lia, and Schotsmans, Martien (eds.). African Perspectives on Tradition and Justice. Cambridge: Intersentia, pp. 67-94.

—. (2015). "Xiconhoca, o inimigo: Narrativas de violência sobre a construção da nação em Moçambique". Revista Crítica de Ciências Sociais, 106, pp. 9-52.

-. (2018). "Colonialismo como Violência: A 'missão civilizadora' de Portugal em Moçambique". Revista Crítica de Ciências Sociais [Online]. Special Issue. <DOI: https://doi. org/10.4000/rccs.7741>.

-. (2019). Os Saberes Feiticeiros em Moçambique: Realidades materiais, experiências espirituais. Coimbra: CES/Almedina.

Merry, Sally E. (2003). "From Law and Colonialism to Law and Globalization". Law and Social Inquiry, 28(2), pp. 569-590, <http:// www.jstor.org/stable/1215784>.

Minter, William (1994). Apartheid's Contras: An Inquiry into the Roots of War in Angola and Mozambique. London: Zed Books.

Morier-Genoud, Eric; Cahen, Michel, and do Rosário, Domingos M. (eds.) (2018). The War Within. New Perspectives on the Civil War in Mozambique, 1976-1992. Suffolk: James Currey. 
Mudimbe, Valentin (1988). The Invention of Africa: Gnosis, Philosophy, and the Order of Knowledge. Bloomington, IN: Indiana University Press.

Nkrumah, Kwame (1970). Consciencism. Philosophy and Ideology for De-Colonization. New York: Monthly Review Press.

Onslow, Sue (ed.) (2009). Cold War in Southern Africa: White Power, Black Liberation. Abingdon: Routledge.

Pereira, Fabião (1999). Particularidades da Dinâmica do Conflito Armado no Distrito do Alto Molócué, 1982-1992. Maputo: BA dissertation, Eduardo Mondlane University.

Ranger, Terence (1985). Peasant Consciousness and Guerrilla War in Zimbabwe. London: James Currey.

Rodney, Walter (1972). How Europe Underdeveloped Africa. Dar es Salaam: Tanzania Publishing House.

Roesch, Otto (1992). "Renamo and the Peasantry in Southern Mozambique: A View from Gaza Province". Canadian Journal of African Studies, 26(3), pp. 462-484. <DOI: 10.1080 /00083968.1992.10804299>.

Sabaratnam, Meera (2017). Decolonising Intervention: International Statebuilding in Mozambique. London: Rowman \& Littlefield International.

Santos, Boaventura de Sousa (2006). "The Heterogeneous State and Legal Pluralism in Mozambique". Law \& Society Review, 40(1), pp. 39-76. <DOI: 10.1111/j.15405893.2006.00258.x>.

-. (2018). The End of the Cognitive Empire: The Coming of Age of Epistemologies of the South. Durham, NC: Duke University Press.

Santos, Boaventura de Sousa and Meneses, Maria Paula (2019). "Introduction - Epistemologies of the South - Giving Voice to the Diversity of the South". In: Santos, Boaventu- ra de Sousa and Meneses, Maria Paula (eds.). Knowledges Born in the Struggle: Constructing the Epistemologies of the Global South. New York: Routledge, pp. 17-43.

Seth, Sanjay (2011). "Postcolonial Theory and the Critique of International Relations". Millennium: Journal of International Studies, 40(1), pp. 167-183. <DOI: 10.1177/0305829811412325>.

Sharma, Ananya (2021). "Decolonizing International Relations: Confronting Erasures Through Indigenous Knowledge Systems". International Studies, 58(1), pp. 25-40. <DOI: 10.1177/0020881720981209>.

Smith, Ian (1997). The Great Betrayal. London: Blake.

Thiong'o, Ngugi Wa (1986). Decolonizing the Mind: The Politics of Language in African Literature. Oxford: James Currey.

Trouillot, Michel-Rolph (2002). "The Otherwise Modern: Caribbean Lessons from the Savage Slot". In: Knauft, Bruce M. (ed.). Critically Modern: Alternatives, Alterities, Anthropologies. Bloomington, IN: Indiana University Press, pp. 220-237.

Vines, Alex (1996). Renamo: From Terrorism to Democracy in Mozambique? London: James Currey.

Weigert, Stephen L. (1996). Traditional Religion and Guerrilla Warfare in Modern Africa. New York: St Martin's Press.

Weinstein, Jeremy M. and Francisco, Laudemiro (2005). "The Civil War in Mozambique." In: Collier, Paul and Sambanis, Nicholas (eds.). Understanding Civil War. Vol. 1. Washington, DC: The World Bank, pp. 157192.

Wilson, Ken B. (1992). "Cults of Violence and Counter Violence in Mozambique". Journal of Southern African Studies, 18(3), pp. 527582. <https://www.jstor.org/stable/2637299>. 